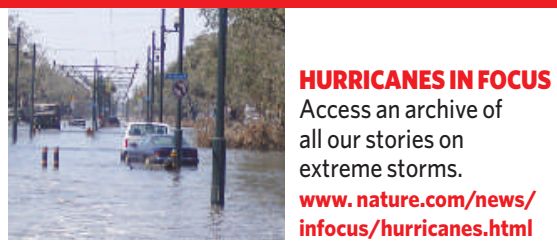

IMAGE

UNAVAILABLE

FOR COPYRIGHT

REASONS

Dirty job: the water is being pumped out of New Orleans, but residues of petroleum, pesticides, garbage and sewage are expected to remain.

\title{
First tests show flood waters high in bacteria and lead
}

As the clean-up operation along the US Gulf Coast gets into full swing, the environmental effects of Hurricane Katrina are slowly coming to light.

Samples of the flood waters swamping New Orleans taken from residential areas between 3 September and 5 September have revealed dangerous levels of lead and coliform bacteria. The US Environmental Protection Agency (EPA) has promised a thorough analysis, and has told people to avoid contact with the waters if possible.

Along with the expected sewage contamination, the waters in New Orleans contain a wide range of chemicals. Some 150,000 submerged cars may have leaked petrol, oil and antifreeze, and an equal number of houses may have contributed asbestos from insulation and lead from paint. Unknown quantities of household pesticides, cleansers and solvents are also likely to be in the mix.

The flooding submerged the Agriculture Street Landfill, a former rubbish dump that, once covered by a protective liner, has been developed into a residential area. No one knows yet whether any of the toxic waste in the landfill has begun leaching through the liner.

"We know the water is bad," EPA administrator Stephen Johnson said last week. The agency has tested for more than 100 chemicals in the flood waters, including volatile organic compounds, pesticides, herbicides and polychlorinated biphenyls.

As of early this week, the only chemical on that list reported to be at dangerously high levels was lead in one residential area. And in a dozen samples taken over three days, all but two swamped the maximum detection level of 2,400 colonies of Escherichia coli per sample. The recommended limit is 126 colonies.

The Gulf Coast is home to much of the US petrochemical industry; reports of damage to chemical and oil facilities are still emerging. Of more immediate concern are the nearly 1,000 drinking-water systems and more than 100 wastewater systems that have been battered by the storm, leaving many in the region without safe water. "Nobody has ever dealt with anything on this scale before," says Jean Kelly, a spokeswoman for the Louisiana Department of Environmental Quality, which is working with the EPA.

Agency officials say that the EPA will release a sampling plan for chemical and biological contaminants within days to weeks, using experts from its science board. Until results come through, it is left to other experts to speculate and worry - not only about the city of New Orleans, but about other shattered Gulf Coast communities and the oil refineries and chemical plants along the Mississippi River.

Many of the old wooden homes in New Orleans may have soaked up toxic compounds from contaminated mud, says Neal Langerman of the chemical consulting firm Advanced Chemical Safety in San Diego. "I expect an awful lot of structures will have to be razed," he says.

Emma Marris

\section{US tests satellite tool for hurricane monitoring \\ The daredevil aircraft that fly into the hearts of hurricanes, including Katrina, could soon be joined by a satellite tool that can make storm planning more effective. \\ Synthetic aperture radar (SAR) can monitor wind speeds and directions inside storms at high spatial resolutions, German and US researchers say. The \\ National Hurricane Center in Miami. \\ The new SAR images (see picture) slightly underestimated the storm's maximum wind speed over the ocean, says Jochen Horstmann, an oceanographer at the GKSS research centre in Geesthacht, Germany. The data are from the European ENVISAT and the Canadian RADARSAT-1 satellites, which monitored ocean surface roughness.} technique, is being tested at the US
Quirin Schiermeier

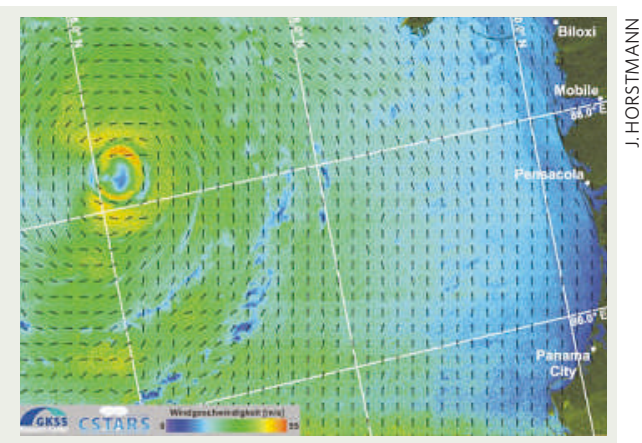

